\title{
The Overlooked Costs of the Permanent War Economy: A Market Process Approach
}

\author{
Thomas K. Duncan ${ }^{\dagger}$ Christopher J. Coyne*
}

\begin{abstract}
:
How does the permanent war economy interact, and subsume, the private, non-military economy? Can the two remain at a distance while sharing resource pools? This paper argues that they cannot. Once the U.S. embarked upon the path of permanent war, starting with World War II, the result was a permanent war economy. The permanent war economy continuously draws resources into the military sector at the expense of the private economy, even in times of peace. We explore the overlooked costs of this process. The permanent war economy does not just transfer resources from the private economy, but also distorts and undermines the market process which is ultimately responsible for improvements in standards of living.
\end{abstract}

JEL Codes: B53, H00, H56, P50

Keywords: War Economy, National Defense, Economic Calculation, Interventionism

\footnotetext{
${ }^{\dagger}$ Email: thomaskduncan@gmail.com. Address: Department of Economics, George Mason University, MS 3G4, Fairfax, VA 22030, USA.

*Email: CCoyne3@GMU.edu. Address: Department of Economics, George Mason University, MS 3G4, Fairfax, VA 22030, USA.

The authors would like to thank the Mercatus Center at George Mason University for its support. An earlier version of this paper was presented at the Annual Meeting of the Association of Private Enterprise Education, Las Vegas, Nevada, April 1-3, 2012. We would like to thank conference participants for useful feedback. We are, also, especially grateful to Peter J. Boettke, Peter T. Leeson, and Caralynn Reddig for their comments and suggestions. The usual caveat applies.
} 
"In the councils of government, we must guard against the acquisition of unwarranted influence, whether sought or unsought, by the military-industrial complex. The potential for the disastrous rise of misplaced power exists and will persist." - Eisenhower (1961)

\section{Introduction}

In 2010 , the United States government spent more on national defense ( $\$ 738.8$ billion) than it did at the height of the Cold War spending in 1986 ( $\$ 572$ billion), when the U.S. was competing in an arms race against the then superpower U.S.S.R. ${ }^{1}$ Rather than facing the threat of a large, consolidated enemy such as the Soviet Union, the U.S. is currently focused on two foreign wars against smaller, decentralized enemies in Afghanistan and Iraq, as well as the seemingly endless transnational War on Terror. Of course, it is not only the public sector that has increased spending for defense purposes. Mueller and Stewart (2011:4) indicate that private sector spending for homeland security has increased by $\$ 110$ billion between 2001 and 2011 .

The business of ending terrorism is a thriving one, and Eisenhower's military-industrial complex thrives along with it. Yet what is the true cost of this thriving complex, where the government and the private sectors intersect? The central argument of this paper is that the costs of that intersection have so far been understated, as they do not take into account the full forgone opportunities of the resources drawn into the war economy. The opportunity costs are far more extensive than those counted simply in defense spending budgets. Indeed, once the United States entered into the state of permanent war, starting with World War II, a new equilibrium was established whereby resources are continuously drawn from the non-military sector to support and advance military-related activities in what has become a "permanent war economy." The

\footnotetext{
${ }^{1}$ Data Source: White House Office of Management and Budget, Historical Tables, Table 15.4. The monetary values are presented in 2010 US dollars.
} 
permanent war economy leads to a reshaping of the private economy through a process that can be summarized as follows.

A state of permanent war leads, inevitably, to a larger military and more military expenditures. The redirected resources dedicated to the military sets in motion a process whereby private market activity is distorted as private actors respond to the opportunities presented by a state of permanent war and adjust their behaviors to take advantage of new profit opportunities. As the state of permanent war persists, the private economy becomes increasingly intertwined with the state. The result is a bloated corporate state and a less dynamic private economy, the vibrancy of which is at the heart of increased standards of living. Therefore, in undermining the private economy, the permanent war economy ultimately stifles the process of wealth creation harming the well being of citizens. The purpose of this paper is to flesh out how this distortive process operates. In doing so, we highlight a cost of the permanent war economy that is typically overlooked when discussing the costs of the U.S. military.

The concern over the military-industrial complex is not a new one. As the opening quote indicates, in 1961 President Dwight Eisenhower warned of the need to maintain vigilance against what he termed the "military-industrial complex." Indeed, he explicitly recognized the rise of a permanent war economy when he noted that:

[W]e have been compelled to create a permanent armaments industry of vast proportions. Added to this, three and a half million men and women are directly engaged in the defense establishment. We annually spend on military security more than the net income of all United States corporations.

This conjunction of an immense military establishment and a large arms industry is new in the American experience. The total influence -- economic, political, even spiritual -- is felt in every city, every State house, every office of the Federal government. We recognize the imperative need for this development. Yet we must not fail to comprehend its grave implications. Our toil, resources and livelihood are all involved; so is the very structure of our society. 
Eisenhower's warning came as a response to the shift in the way the nation's defense had been undertaken since World War II. By the end of the war, the idea of defense had become one of constant preparation for future wars and foreign interventions rather than an exercise in response to one-off threats. The military and private industry combined their efforts in an attempt to keep the U.S. forever in a state of military readiness. As per Eisenhower's speech this paper analyzes some of the "grave implications" of the military-industrial complex for the structure of the private economy.

The economics profession has not let Eisenhower's words go entirely unheeded. Raymond (1964) argues that free enterprise becomes less free as it becomes more associated with the defense industry. In the name of national security, businesses dealing in defense come under the direct scrutiny of the Pentagon and its industrial security officer, increasing the red tape and overall costs of doing business. Melman (1971) explores the role of Robert McNamara in centralizing the military-industrial complex beneath the Department of Defense and explains how political clout becomes the currency of the complex. The later work of Melman (1985) builds upon his earlier piece, giving an in-depth description of how the permanent war economy furthers the politicization of those involved in the complex. Higgs $(1987 ; 2004 \mathrm{a} ; 2005 ; 2006$; 2012) describes how the state derives its power from historical crises, especially wars, growing in size to deal with each one and never quite giving up as much power as it gained once the crisis passes. This pattern gives rise to what he refers to as the "ratchet effect," with incremental growth in state size and authority over time. Finally, Rockoff (2012) analyzes a century of American foreign policy to understand how these efforts were financed in order to understand how war has influenced the U.S. economy. 
Neither has the idea of opportunity cost gone entirely unrecognized in the economics literature on national defense. Economists as early as Adam Smith recognized that war is a costly endeavor, and an empire that grows too large will find itself difficult to protect. In writing on the costs of protecting and enforcing British imperialism he notes, "The interest of this [military] debt alone is not only greater than the whole extraordinary profit which it ever could be pretended was made by the monopoly of the colony trade..." (Smith 1776: 180). The efforts to both protect and intimidate the satellites of the British Empire were bankrupting the Empire itself. In more modern economics, Oi (1967), and later Henderson (2005), acknowledge the understated costs of the military draft that was kept in effect in the United States until 1973. Milton Friedman (1976), along with the aforementioned writings of Oi and Henderson, argue that the budgetary cost for military personnel during those draft years was understated due to its failure to take into account the opportunity cost in terms of the voluntary private employment forgone by the draftees.

There are also attempts to calculate the forgone opportunities of resources used in the military-industrial complex. Russet (1971) uses Gross National Product (GNP) calculations to estimate first the losses to productivity in the private sector and then the losses to investment in other areas of the public sector. Higgs (2006) constructs similar calculations of GNP to make the distinction between "butter-sacrificing" during military buildup and "butter-enhancing" during a demobilization period. He shows empirically that "[c]hanges in the [Government Military] and [Private] shares [of Gross National Product] were almost exactly offsetting. A trade-off equation fitted to the annual changes during $1948-89$ has a tight fit $(R 2=0.814)$ and shows that the implicit cost of a one-percentage-point increase in the military share was a reduction of one percentage point in the private share" (Higgs 2006: 132). 
Yet even these previous works do not tell the full story. While mobilizations and demobilizations will have tradeoff effects, it does not speak to the full costs of a permanent war economy. The permanency of the war economy means that the distortions last far longer, and extend far deeper into the private economy, than those suffered in the emergency of actual war. An accounting measure of the economy cannot fully realize the foregone alternatives in entrepreneurial activity. The advent of the permanent structure of the military-industrial complex introduces a situation that creates "pure profit opportunities that would otherwise have been absent" which "simultaneously reduce or possibly eliminate other opportunities for pure profit that might otherwise have existed" (Kirzner 1985: 144). The new equilibrium establishes incentives to further invest in military-related activities, creating further divergence from what would have been and thus greater costs in terms of forgone opportunities.

The remainder of this paper is organized as follows. Section 2 provides some indicators of the magnitude of the permanent war economy with the purpose of highlighting the resources that are redirected from the non-military to the military sectors. Section 3 explores the changing equilibrium in terms of Kirzner's (1985) un-simulated, stifled and superfluous discovery processes, then analyzes the encroachment of the permanent war economy upon the non-military economy in terms of the dynamics of interventionism (see Mises [1920] 1990, [1929] 1996, [1949] 2007; Ikeda 1997, 2005). Section 4 concludes with the implications of our analysis.

\section{The Permanent War Economy}

In his analysis of American foreign policy over the past several decades, the historian Andrew Bacevich (2010) concludes that the U.S. has been in a state of "permanent war." This state, which began during the Second World War, is defined by a global military 
presence and projection of power through constant foreign interventions under the rhetorical guise of maintaining international "peace and order" (Bacevich 2010: 14). This state of permanent war is sustained by a massive military complex which consists not just of the existing government bureaucracy, but also of think tanks, lobbyists, security experts, and businesses that provide the complex with technocratic advice and resources to maintain its global presence. To begin to understand the magnitude of this reality, consider the following data.

The United States routinely spends more on defense than any other nation. To be more accurate, the United States is responsible for nearly half of all world military spending. Friedman and Preble (2010) and the International Institute of Strategic Studies (2010) show that U.S. transactions in 2008 accounted for 48 percent of military spending around the globe for that year. Figure 1 provides a breakdown by region. 


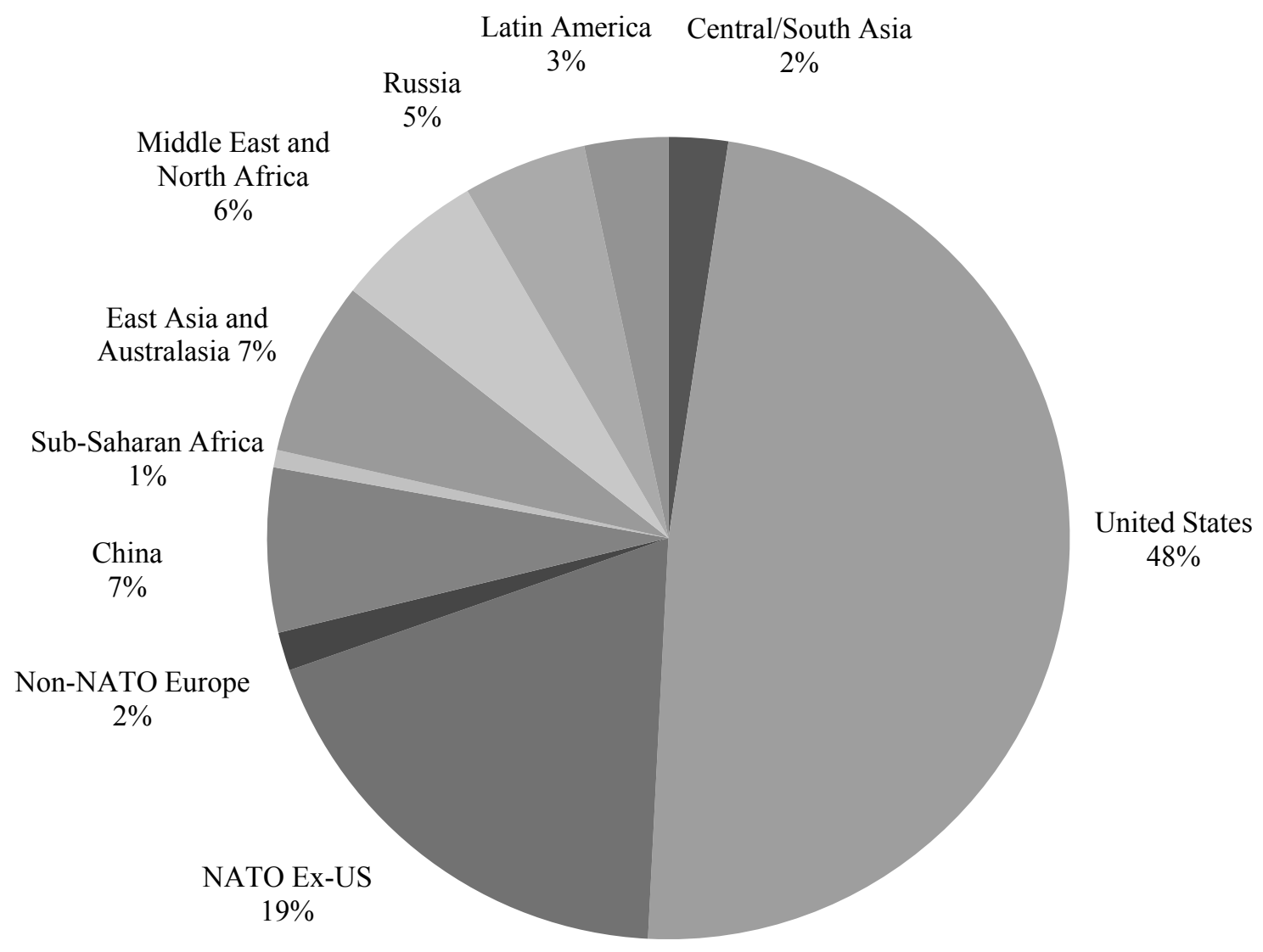

Figure 1: Global Military Spending ${ }^{2}$

The next highest spender is the conglomeration of U.S. allies under North Atlantic Treaty Organization (NATO) which, even as a collective organization of developed nations, still accounts for 29 percent less military spending than does the U.S. by itself.

Next, consider annual defense spending by the U.S. Since the demobilization following World War II, defense spending has shown an upward trend, though there have indeed been some periods of spending decline. As Figure 2 shows, however, there is a sharp increase from 1948 into the early 1950 s from just over $\$ 100$ billion to more than $\$ 400$ billion per year; since that spike, defense spending has never dropped below $\$ 350$ billion per year. The U.S. spent more

\footnotetext{
${ }^{2}$ Source: International Institute of Strategic Studies, The Military Balance 2010. See, also, Friedman and Preble (2010: 4).
} 
on defense in 2010 than it spent in 1986, the height of the Cold War, by over 29 percent. Put simply, there has been a nearly 30 percent increase in spending to fight a variety of enemies not classified as a world super power, as the Soviet Union was through the 1980s. ${ }^{3}$

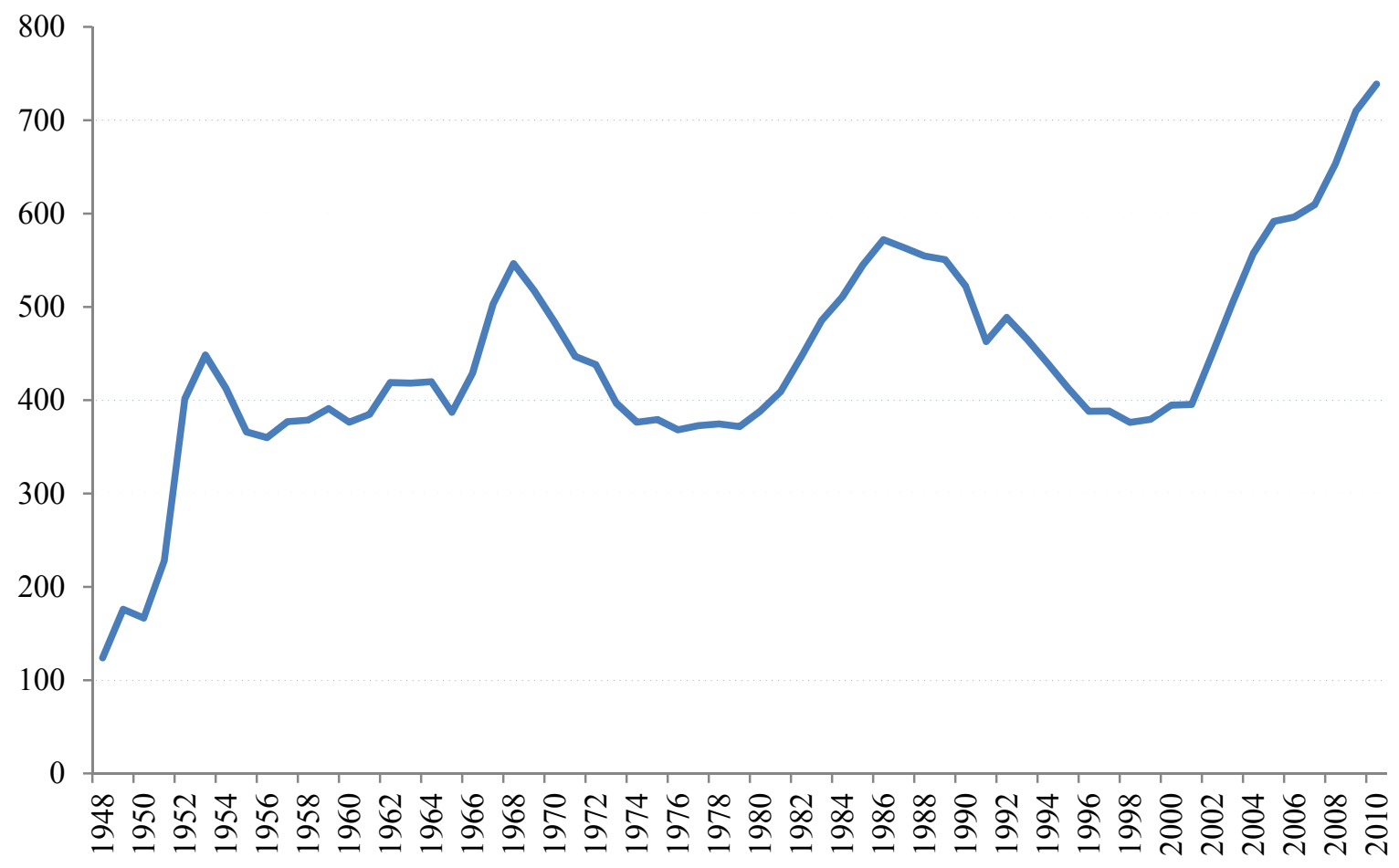

Figure 2: U.S. Defense Spending: 1948-2010 (billions of 2010\$) ${ }^{4}$

Separated by decades, the United States has spent 38 percent more between 2001 and 2010 than between 1991 and 2000. It has spent 12.5 percent more in that same decade than between 1981 and 1990, when the Soviet Union was considered a serious military and nuclear threat. In the decade since 2001, the official Department of Defense budget has grown at an average "rate of more than 12 percent every year" compared to non-defense discretionary spending which has

\footnotetext{
${ }^{3}$ Note that the current enemy combatant forces, those of Iraq and Afghanistan, are from the region of the Middle East. Figure 1 shows that in 2008, the entire Middle East region, combined with that of North Africa, accounted for only 6 percent of global military expenditures, some 42 percent less than that spent by the United States.

${ }^{4}$ Source: White House Office of Management and Budget, Historical Tables, Table 15.4.
} 
grown at a rate of "8 percent per year" (Preble 2009: 8). To provide some context, in the decade prior to 1986, during the arms race, the average annual rate of growth of discretionary defense spending was 6 percent. $^{5}$

The increase in military expenditures should not be mistaken as a simple increase due to ongoing wars. While the wars in Iraq and Afghanistan have, of course, greatly impacted the level of defense spending, direct spending on these efforts does not account for all of the defenserelated growth. As Table 1 indicates, since the 9/11 attacks there has been substantial growth in spending on areas such as the Pentagon base budget, nuclear weapons, and homeland security.

\begin{tabular}{|c|c|c|c|c|}
\hline & Total Spending & 2001 Amount & 2011 Amount & $\begin{array}{c}\text { \% Increase } \\
\text { 2001-2011 }\end{array}$ \\
\hline $\begin{array}{c}\text { Pentagon Base } \\
\text { Budget }\end{array}$ & $\$ 5.5$ trillion & $\$ 357.7$ billion & $\$ 510$ billion & 43 \\
\hline Nuclear Weapons & $\$ 226.4$ billion & $\$ 15.3$ billion & $\$ 18.4$ billion & 21 \\
\hline $\begin{array}{c}\text { Iraq and Afghan } \\
\text { Wars }\end{array}$ & $\$ 1.34$ trillion & $\$ 20.2$ billion** & $\$ 162.8$ billion** & $707 * *$ \\
\hline Homeland Security & $\$ 625$ billion* & $\$ 19.7$ billion & $\$ 67$ billion & 240 \\
\hline $\begin{array}{c}\text { Atomic Energy } \\
\text { Defense }\end{array}$ & $\$ 204.45$ million $^{\alpha}$ & $\$ 15.92$ million $^{\alpha}$ & $\$ 20.28$ million $^{\alpha}$ & $27^{\alpha}$ \\
\hline
\end{tabular}

Table 1: Defense Spending 2001-2011 (2010\$) ${ }^{6}$

\footnotetext{
${ }^{5}$ Percentage calculated from the White House Office of Management and Budget, Historical Tables, Table 8.7. The date range used is 1979-1986, in an attempt to give a time span equitable to that used by Preble (2009). Using the full decade, from 1976-1986, the average increase falls to 4 percent each year.

${ }^{6}$ Source: “U.S. Security Spending Since 9/11,” National Priorities Projects, May 2011.

[http://nationalpriorities.org/en/publications/2011/us-security-spending-since-911/]. *NOTE: This figure includes $\$ 161$ billion funded through the Pentagon's "base" budget. Total "non-defense" homeland security spending is $\$ 464$ billion. **Source: Belasco (2011). Belasco (2011) gives the 2001 Amount for the Iraq and Afghan wars as a combined total for FY 2001-2002, meaning \% Increase given here is understated. ${ }^{\alpha}$ NOTE: Calculated from the White House Office of Management and Budget, Historical Tables, Table 3.2.
} 
The expansion of funds spent on homeland security has been immense, increasing over 240 percent over the course of a decade. In conducting their cost-benefit analysis of the homeland security industry, Mueller and Stewart (2011: 81) note that between 2001 and 2009,

Some 44 percent of this expenditure is devoted to preventing and disrupting terrorist attacks through policing and intelligence efforts, and another 46 percent to protecting the American people, critical infrastructure, and key resources, while 9 percent is devoted to responding to and recovering from incidents. Funding goes to the DHS, the Department of Defense, the Department of Justice, the Department of Health and Human Services, the Department of Energy, and 26 other federal agencies...

The funds going into most of these different departments and agencies show an increase for the given time span. In tracing only "homeland security"-related spending, Mueller and Stewart (2011: 2) show that between 2003 and 2011, there has a 61 percent increase from the Department of Homeland Security, a 126 percent increase from the Department of Defense, a 31 percent increase from the Department of Health and Human Services, an 82 percent increase from the Department of Justice, and a 256 percent increase from the Department of State.

It is also interesting to note from Table 1 that spending on nuclear weapons has risen 21 percent over the past decade, though neither Iraq nor Afghanistan is capable of producing its own nuclear weapons. ${ }^{7}$ U.S. expenditures on atomic energy defense activities have increased by approximately 27 percent throughout the 2001-2011 period, and although Table 1 only spans the most recent decade, there has been an increase of approximately 37 percent in atomic defense spending since the high point of the 1986 arms race. ${ }^{8}$ These increases have taken place even though the use of nuclear weapons has not become a staple of modern warfare, having only been actively used militarily by the U.S. during World War II. As both the case of nuclear weapons

\footnotetext{
${ }^{7}$ Mueller and Stewart (2011: 66-70) give a brief historical account of the fear of atomic terrorism and explain why those fears are largely exaggerated.

${ }^{8}$ Percentage calculated from the White House Office of Management and Budget, Historical Tables, Table 3.2. In 1986 , the U.S. spent $\$ 14.8$ million, inflation adjusted, on atomic energy defense.
} 
and of atomic energy defense illustrate, the state of permanent war in the U.S. has led to a permanent war economy whereby a variety of military programs are sustained and expanded even if the benefits of maintaining, and certainly increasing, those programs are unclear.

Of course, resources drawn into the war economy are more than just the dollars spent as constant war preparation also shapes the constitution of the labor force. Consider, for instance, that according to the Bureau of Labor Statistics, in 2008, the Defense and Homeland Security departments made up nearly 49 percent of civilian employment in the federal government. ${ }^{9}$ The U.S. military alone has $1,580,255$ men and women on active duty, with the Army carrying the brunt of that force with 662,232 in service. ${ }^{10}$ Beyond those men and women listed as "active," there are 11,035 civilians and 864,547 reservists in military employ. Each of these men and women represents a valuable economic resource in terms of education and the alternative opportunities he or she could find in the private, non-military workforce.

As these data indicate, the state of permanent war consumes significant resources. These resources are redirected from the private, non-military sector into the military sector creating a permanent war economy. However, the measures in this section are insufficient to show the true cost of the complex, as an accounting measure of the economy cannot fully realize the foregone alternatives in entrepreneurial activity. The essence of this point is captured by Higgs (1993: 34) who notes that "by diverting workers and resources to a bloated, privileged, anticompetitive procurement complex, war buildups have actually reduced the American capacity to invent, innovate, and enhance productivity along nonmilitary lines." As costly as the finite military buildups are to the health of the non-military economy, it is the continuing presence of the

\footnotetext{
${ }^{9}$ Excludes the U.S. Postal Service and defense oriented organizations such as the CIA, where such information is classified for reasons of national security. See Table 1 here: [http://www.bls.gov/oco/cg/cgs041.htm].

${ }^{10}$ Figures for the remainder of this paragraph are drawn from the International Institute for Strategic Studies' The Military Balance 2010.
} 
industrial-war complex that has long-lasting distortive effects on the process of private, productive economic activity.

\section{The Overlooked Perils of the Permanent War Economy}

In general, Kirzner (1985: 136) argues that government interventions into the private economy "generate new (unintended and undesired) processes of market adjustments that produce a final outcome even less preferred than what might have emerged in the free market." The interaction between the military and the private economy, from which resources are pulled to finance the former, has the same effect as other government interventions in that the permanent war economy creates an entirely new set of market and pseudo-market circumstances. The nature of these new circumstances results in entrepreneurs engaging in alternative, unproductive entrepreneurial activities which undermine the efficiency of the market economy.

\subsection{The Fundamental Problem of Economic Calculation}

In recent years, Secretary of Defense Robert Gates has made the suggestion that the Department of Defense must be more cognizant of the way in which it undertakes military procurement (Gates 2009, 2010; Gates and Mullen 2011). For example, in a press release dated April 6, 2009, Gates stated that his "department must consistently demonstrate the commitment and leadership to stop programs that significantly exceed their budget or which spend limited tax dollars to buy more capability than the nation needs." The following year, Gates reiterated the need for a more economical approach to military spending, stressing his hope that "Congress will work with us to 
reduce unnecessary costs..." (Gates 2010, emphasis added). Though the rhetoric used suggests a turn towards greater efficiency, these statements do not address the fundamental economic questions of how much military capability the nation needs or, along the same vein, what constitutes necessary versus unnecessary costs for obtaining those capabilities.

Implicit in Gates's desire to reduce "unnecessary costs" is the importance of achieving allocative efficiency when making procurement decisions. ${ }^{12}$ Resource scarcity necessitates a method of choosing among tradeoffs, whereby the purpose of said method is to ensure that in making that choice resources are allocated to their highest valued use. In a general, stylized sense resource allocation can be achieved through one of two ways. Either resources are allocated through individual exchange within a market setting, or they are allocated by administrative authority, e.g., central planning. These two options have dramatically different implications for the efficiency of outcomes.

Under a market arrangement, goods and services are exchanged via the actions of voluntary buying and selling. Producers and consumers coordinate their activities based on the feedback mechanisms of monetary prices and profit and loss. These mechanisms allow economic actors to engage in economic calculation, because on the unhampered market, prices provide a common denominator with which individuals can calculate relative values of alternative goods

${ }^{11}$ Gates (2010) makes this statement in reference to the Congress's previous actions that hamper resource reallocation within the Department of Defense for political reasons. The full quote reads, "I've also authorized each of the military departments to consider consolidation or closure of excess bases and other facilities where appropriate. This is obviously a politically fraught topic. Currently, Congress has placed legal constraints on DOD's ability to close installations. But hard is not impossible, and I hope Congress will work with us to reduce unnecessary costs in this part of the defense enterprise." For a fuller explanation of Congressional restrictions on base closures, see Twight (1990).

${ }^{12}$ One counter to the claimed desire for "maximizing social welfare" is that Gates, and the defense industry in general, are seeking to maximize security rather than welfare. However, such a counter would only push the frontier of the argument outward to beg the question of how much security is demanded. Consumers do not demand 100 percent security at the expense of all else, as is evidenced by the fact that people continue to drive to work or walk across the street. Consumers want to maximize security subject to a budget constraint. The question of the efficient tradeoff between security and all other goods remains fundamentally an economic question of social welfare maximization. 
and services, and a system of profit and loss provides feedback as to whether or not resources are being channeled to their most socially valued use. ${ }^{13}$ When an output generates a profit on the market, this signals to the producer that the resources are being used in a valuable way from the standpoint of consumers; the corollary is that should an output be produced at a loss, the signal is sent that what has been created is not as valuable as the alternatives toward which the resources could have been put. The constant feedback of this profit and loss system generates an outcome in which the diverse plans of disparate economic actors are coordinated into socially desirable outcomes. The market alternative appreciates that the knowledge of the optimal use of scarce resources is not given ex ante, but instead must be discovered through the process of individual choice (Mises [1920] 1990, [1922] 1981, [1949] 2007; Hayek 1945; Thomsen 1992).

Under the administrative, or centrally planned, arrangement, resources are allocated to produce outcomes according to the administration's preferences rather than the demand of the consumers. The central planner asserts his plan over the disparate plans of other individuals, based on a predetermined end of his own. This exercise relies on the top-down imposition of plans rather than on the emergent discovery and coordination that takes place in markets. As the output at the end is not sold for a market price, but rather is distributed based on the overarching plan, the system of profit and loss is unable to provide a sufficient method of determining social welfare calculations. Instead, planners must rely on alternative measures in an attempt to approximate the same results, methods which do not provide the same information as that generated through the market process (see Hoff 1949; de Soto 2010).

The method of resource allocation for the defense industry falls much closer to the centrally planned, administrative arrangement. The Defense and Homeland Security Departments, the President, and the Congress come together at various stages of the budgetary

\footnotetext{
${ }^{13}$ For further discussion of the unhampered market, see Mises ([1949] 2007).
} 
approval process to decide on both the level and direction of funding and the goals of the national security sector. Within the bounds of the budgetary decisions, contracts are negotiated between the Departments and the individual defense firms. Elberton Smith, the official historian of the U.S. army's economic mobilization during the World War II period, notes these centralizing tendencies as he chronicles the military buildup immediately prior to the Second World War. In describing this tendency, he argues that,

As the nation moved rapidly through the defense period into a wartime economy, many of the functions of the traditional price system were supplanted to an unprecedented degree by direct controls. The allocation of basic industrial materials, to facilitate both the creation of industrial capacity and the production of finished munitions, was accomplished increasingly by administrative decisions and procedures stemming directly from the character of national war production objectives ([1991] 1959: 311).

The reliance on central decision making in military-related matters is one that persists to this day.

However, if efficiency concerns are relevant this arrangement is problematic because as Higgs (2006: 133) notes, "no one knows the production function for national security" and the optimal level of defense is not a given. Rather than relying on the market feedback mechanisms to ensure that consumers are getting the level of security they demand, the level of security is determined administratively and asserted over the consumers who have no, or at best a weak, avenue of recourse should that level prove undesirable. The nature of the budgetary process does not allow for profit and loss in the economic, or market, sense. ${ }^{14}$ And while the administration may cancel (reduce) or grant (increase) funding for specific defense programs, these decisions are based on

\footnotetext{
${ }^{14}$ Even the relative values at work in the war economy are suspect. In critiquing the conventional use of national income and product accounts data as a measure of defense spending impact, Higgs (2006) provides a further discussion of the market-military disconnect, arguing that "because the prices paid for defense goods and services generally are not - and, in some cases, cannot be - determined within a competitive market framework, all such prices are suspect. What do they mean? Is there any reason to suppose that they approximate consumers' marginal rates of substitution or producers' marginal costs? If not, why should the actual prices paid be regarded as appropriate weights for the purpose of aggregating physically incommensurable goods and services?" (2006: 133) While the prices exist, they do not convey the same information as those determined via the unhampered market. Rather, the prices here operate in more the accounting sense than in the economic one.
} 
the central plan rather than on market information which is crucial for reallocating scarce resources to their highest valued uses. As such, there is a military-to-market disconnect which allows unnecessary costs in the form of misallocated resources to persist for significant periods of time due to the absence of information regarding higher value-added resource allocations.

This is problematic because persistent resource allocations lead to broader distortions within the market process, well beyond the initial transfer of resources from the private to the military economy. The nature of this distortive process can be understood as follows. The lure of profit created by the new, military-related, opportunities draw talented entrepreneurs from the private to the military sector. In pursuing these initial profit opportunities, entrepreneurs create entirely new profit opportunities in the military sector. As Holcombe (1998: 46) argues, “[e]ntrepreneurial ideas arise when an entrepreneur sees that the ideas developed by earlier entrepreneurs can be combined to produce a new process or output" and "acts of entrepreneurship create an environment within which innovations build on themselves" (1998: 47). In other words, with each new entrepreneurial discovery comes an array of future profit opportunities. ${ }^{15}$ In the context of military activities, consider the example of unmanned aerial vehicles (UAVs) or "drones.”

Originally developed to mitigate the fatality risk of surveillance (and attack) on military targets, drones have become increasingly utilized by the Department of Defense overseas. The existing and perceived capabilities of the drones, combined with the lure of profits from an

\footnotetext{
${ }^{15}$ To reiterate, the argument here is not to say that the defense sector cannot increase defense outputs; it can and often does as is evidenced by the increased spending in homeland security. However, as there is no method for determining whether such outputs are socially valued, when investments in the defense industry continue, above the socially optimal level, the military economy becomes and continues to be over-capitalized*. The over-capitalized defense sector provides resources for further entrepreneurial discoveries, both in terms of new defense programs and technological advances in currently operating ones, which are above the "market rate"** of military entrepreneurship. *Note: For a fuller explanation of the function that economic loss serves as a check on overcapitalization, see Rothbard ([1962] 2001: 463-469). **Note: "Market rate" here refers to the rate of entrepreneurial discoveries that would be established under the alternative market-oriented institutional arrangement.
} 
expanded use of UAVs in other ways have led the members of the UAV industry to actively seek to expand the drone market. The result has been an increase in the non-military use of drones not just internationally, but also domestically. Not only are drones now being used to patrol the U.S. borders $^{16}$ (Schultz 2011), but they are also being outfitted for "dozens of nonmilitary uses...ranging from law enforcement to firefighting to wildlife monitoring" as well as "news coverage, mapping and agricultural applications" (Pasztor and Emshwiller 2012). Entrepreneurs are continuously exploring new ways of refining and exploiting current drone technologies for their specialized markets, even going so far as to invest significant resources in creating demand for their product among the national and local governments (Schulz 2012) ${ }^{17}$. The expanded use of drones, in turn, has led to the subsequent opportunities in the form of a secondary, dronerelated industry built around training, consulting, and support services (Neild 2012). The drone industry, as well as this secondary industry, has invested significant resources in lobbying governments to secure contracts for their services (Bennett 2012; Stone 2012). As this example illustrates, there is a multiplier effect associated with entrepreneurial activity.

While this multiplier effect of entrepreneurial activity is a positive force for economic growth and improved well being in a market setting due to efficiency-enhancing innovation, in the administrative setting there is no guarantee that the same entrepreneurial activity will yield benefits from an efficiency standpoint. Should the discovery process begin with a distorted profit opportunity, additional connected discoveries can lead to greater resource misallocations which persist for prolonged period of time with no mechanism for correction. Even if we assume that

\footnotetext{
${ }^{16}$ Schultz (2011) reports on the increasing use of unmanned aerial vehicles along the U.S.-Mexico border in an attempt to reduce breaches of said border.

${ }^{17}$ Schulz (2012) notes the strategic difference between General Atomics Aeronautical Systems, who provides the Predator drones to the Department of Homeland Security, and AeroVironment, "that builds much smaller "minidrones,' which fit a growing demand by emergency responders, firefighters, and law enforcement agencies." Though both companies do sell within the defense industry, they are investing resources into making their products more marketable domestically, as well.
} 
the initial military-related activity is value-added in terms of providing effective defense, which is a large assumption absent economic calculation as a feedback mechanism, that initial activity will generate future profit opportunities which may very well fail to be value added as future entrepreneurs seek to capture the windfall profits through the political, as compared to the market, process. ${ }^{18}$

As further illustration, consider the claim that the U.S. reaction to the terrorist attacks of September 11, 2001, has led to government inflation of security threats (Mueller 2006; Mueller and Stewart 2011). The previous figures, given in Table 1, show the marked increase and continued increasing trend in protective measures taken by the Departments of Defense and Homeland Security since the 9/11 attack. The total increase since 2001 has been approximately 240\%, yet Mueller and Stewart (2011: 40-55) find no upward trend in the risk of a U.S. citizen's death as a result of a terrorist attack, and possibly a decreasing trend since 1998. In fact, shortly after incurring the initial losses from $9 / 11^{19}$, private insurance firms reentered the terrorism insurance market, and

by 2009 the median terrorism insurance premium for a $\$ 303$ million property had more than halved to only $\$ 9,541$ per year. This represents a conservative measure of expected loss or risk, and a simple back-calculation in the risk equation suggests that the insurer estimates the likelihood of a terrorist attack on a property to be very low: less than one in 30,000 per year (2011: 24).

The authors then question why the Department of Homeland Security is unable to estimate terrorism risks while the private sector is both capable and "willing to risk its own money on the validity of the estimate" (2011: 24). The answer to this question lies in the difference between

\footnotetext{
${ }^{18}$ The political process will be explored more fully in section 3.2.

${ }^{19}$ Mueller and Stewart (2011: 23-24) note, "In the immediate aftermath of the 9/11 attack in which insured losses reached $\$ 35$ billion, most insurance firms placed terrorism exclusions on their policies. Since then, however, the U.S. government implemented the Terrorism Risk Insurance Act to provide 'a temporary window of reinsurance relief to help insurers manage the ongoing risk of terrorism.' With that, insurance firms reentered the terrorism insurance market..."
} 
the private sector economy and the administrative nature of the military-industrial complex discussed above. Under a market setting, where the price and profit and loss mechanisms are functioning, the over-assessment of risk would be competed back to more reasonable levels. As Mueller and Stewart (2011:23) argue, the "insurance industry has a distinct financial imperative to understand terrorism risk." However, the war economy does not provide the same recourse to the mechanisms found in the non-military economy.

The case of terrorist insurance market is somewhat unique in the defense industry in that the estimates of the private insurers provide a market rate for security alongside administrative approximation of risk premiums. The disparity is striking, and it is suggestive of what may be a typical disparity between the social welfare maximizing rate of security provision and the rate at which the military-industrial complex provides defense. From this overabundance of state granted funds come opportunities to collect with such entrepreneurial efforts as developing Advanced Imaging Technologies (AIT) scanners for use in airports ${ }^{20}$, refining technologies for the domestic use of Unmanned Aerial Vehicles ${ }^{21}$, and reengineering strategies for dealing with nuclear bomb threats ${ }^{22}$.

When the defense sector reacts to situations in such a way, the administrative decision making procedure does not provide the same heavy-handed correction as the market's economic loss function. More importantly, when the military sector is providing above the social welfare maximizing level of security on a permanent basis, the lack of a proper feedback mechanism

\footnotetext{
${ }^{20}$ As Mueller and Stewart (2011: 148) note, the "TSA began rolling out the scanners in 2009 and says it plans to procure and deploy 1,800 of them by 2014 to reach full operating capacity at all checkpoints in the United States... We can infer then that the full quota of 1,800 units will cost approximately $\$ 1.2$ billion per year". The authors then perform a risk assessment, computing the marginal gain in security to be well below the value of the price tag for these machines (Mueller and Stewart 2011: 149-152).

${ }^{21}$ See previous citation to Pasztor and Emshwiller (2012). Also, the non-profit research organization Public Intelligence (2012) provides a map of current and future drone sites, found at http://publicintelligence.net/dod-usdrone-activities-map/

${ }^{22}$ For more on the overreaction of federal agencies to nuclear threats post-9/11, see Mueller and Stewart (2011: 166171).
} 
remains permanently. Absent such feedback, the abnormal availability of resources already being diverted into the war economy will reinforce the entrepreneurial process as it leads to ever increasing entrepreneurship in the national security sector.

It is not only problematic that the epistemological indeterminacy, due to the lack of market pricing and profit and loss, establishes a situation in which there is potential to overestimate the optimal level of defense; it is further problematic that this situation is everpresent due to the structure of the military-industrial complex. Not only may responses to crises be overblown, but there is also no method of discovering errors in periods where crises are absent. Higgs's (2006) “butter-sacrificing” economic activity continues well beyond the military buildup, and when "people abandon their otherwise most-valued forms of production..., socially valued outputs are lost (Higgs 2012: 22)" continuously. Of course the costs of these diverted resources can never be calculated since they entail a counterfactual of what would have happened absent the windfall profits associated with the war economy. However, given the high level of adaptability and efficiency promoted by private markets, relative to the inefficiencies of the political marketplace (which will be further discussed below), it is reasonable to conclude that this reallocation of entrepreneurial talent from the private economy to the war economy results in efficiency loses.

\subsection{Rent-Seeking Replaces Market Competition}

The previous subsection stressed the epistemological perils due to the lack of a functioning market system in the defense sector. Yet the political process that replaces the market process has its own method of functioning and generates a set of incentives distinct from those generated in market settings. Though the questions of what to produce and how much to produce continue to lack an economic solution, there does exist a mechanism for deciding who will produce a 
given good. In other words, a system of competition still exists within the permanent war economy, even if it is not one that necessarily leads to economically efficient outcomes. This competition, however, is not driven by the wants of private consumers, but instead by the desires of government bureaucrats who are ultimately responsible for making decisions regarding who will supply military-related goods and services. In response to the incentives created by the political process, private producers redirect resources from meeting the wants of consumers, to meeting the wants of bureaucrats. This further undermines the dynamism of the market economy by weakening the link between production and the satisfaction of consumers wants.

As an example to illustrate this logic, consider Lockheed Martin's F-35 Joint Strike Fighter (JSF) program. Originally launched in the 1990s, and given an extra boost under the Clinton administration in 1994, the JSF program was intended to create a multiservice fighter aircraft designed for use across the lines of Navy, Air Force, and Marines, as well as for sale to the United Kingdom who wished to use the F-35 to replace the British Sea Harriers (Preble 2009: 43-44). The availability of windfall profits for this program has been substantial. As Preble describes,

Given the large number of potential customers, both by the three branches of the U.S. military and in foreign markets, the JSF contract was expected to be the most lucrative in the history of military aviation. Not surprisingly, the competition to design and build the aircraft was intense. Lockheed Martin and its development partners were awarded the contract in October 2001, beating a team led by Boeing (Preble 2009: 44).

Yet in an administrative institutional arrangement that does not allow for a true market competition, this intense competition takes place through politics rather than on the margins of price and profit and loss.

In summarizing the rise of the military-industrial complex, Higgs (2007: 308) suggests that in the defense economy post-World War II, "deals came to turn not on price, but on 
technical and scientific capabilities, size, experience, and established reputations as a military supplier - vaguer attributes that are easier to fudge for one's friends". Melman (1985: 35) describes the war economy's political competition as a system in which "military-industrial firms compete with each other, but, in their race for fresh contract and capital grants from the Pentagon managers, they do not vie for who can achieve a lower product price and cost but rather who can compete best in terms of a display of 'competence'.,23 He concludes that "while militaryindustry firms compete, often in much the same fashion as division managers under a central corporation, in their Pentagon-dominated world 'competence,' including political clout, is the coin of competition rather than the price-quantity contest that is more characteristic of civilian firms" (Melman 1985: 35).

To use the F-35 program as further illustration, one can see the steps taken by members of the defense industry in order to ensure their "political clout" is sufficient to the task of attaining contracts. In attempting to make themselves more attractive to the Pentagon, both Boeing and Lockheed Martin engaged in rounds of mergers and acquisitions to expand their political base. Hartung (2011: 20-21) summarizes these mergers and acquisitions, describing Boeing's purchase of fellow defense industry McDonnell Douglas ${ }^{24}$ and Lockheed Martin's partnership with both British Aerospace and Northrop Grumman. He notes that

[a]lthough Boeing was able to beef up [with] McDonnell Douglas... British Aerospace came over to join the Lockheed Martin Team. This gave Lockheed Martin a leg up in persuading Britain to weigh in on its behalf. It is one thing to have a given state or senator in one's corner. It is quite another to have a

\footnotetext{
${ }^{23}$ Melman (1985: 35) defines competence as "the readiness and ability of the particular firm to satisfy the Pentagon's requirements in the judgment of its top management. It means its ability to collaborate with the Pentagon-level administrators to turn out the sort of product that the Pentagon wants with regard to details of product designing, testing, producing and servicing."

${ }^{24} \mathrm{McD}$ onnell Douglas was an early contender in the competition for the JSF contract. The firm was attempting to salvage the forthcoming losses from both its F-15 and F-18 fighter programs, both of which were to be replaced by varying versions of the new F-35 JSF. Once McDonnell Douglas fell from competition, the firm offered itself to Boeing in order for Boeing to stay competitive with Lockheed Martin. (see Hartung 2011: 20)
} 
sovereign state and longtime U.S. ally like the United Kingdom ready to go to bat for you (2011: 21).

Lockheed Martin further sealed its victory by reaching out to partner with Northrop Grumman, offering the large defense firm "at least 20 percent of the work on the plane. This agreement gave Lockheed Martin even greater pork barrel clout and created a vested interest in key districts and states where Northrop Grumman had operations" (Hartung 2011: 21). Having managed to spread its political ties over a greater area, Lockheed Martin managed a successful contract campaign.

Given this method of achieving contracts - one based on continuous lobbying and sycophancy - once programs are started they become notoriously difficult to cancel. An array of vested interests emerges, and both firms and members of Congress with ties to where these firms operate will fight for continuation in the face of waste or irrelevancy in terms of use of output. Even Secretary of Defense Robert Gates has noted this concern in his attempts to prioritize the war economy as discussed earlier. ${ }^{25}$ However, it is not only a matter of sustaining programs. The concerns are even greater. To re-center the argument in terms of our prior discussion of economic calculation, there are two main points.

The first point is that without a meaningful market price and a system of profit and loss, it becomes unclear to what extent existing programs are aiding in security versus the extent to which they exist for purely political reasons. Even for all the fierce competition and restructuring that took place for the JSF contracts, the central economic question was forgotten. As Preble (2009: 45) asks, "how urgent is the need for the next-generation fighter...?" What is the added value of the newly created fighter in terms of military capabilities? There is some indication that the increase is minimal when one takes into account the fact that such fighters are "facing only a

\footnotetext{
${ }^{25}$ Though Gates does make note of the fact that the defense industry has a propensity to become filled with largess, the institutional arrangement remains one that facilitates this process. Even as he closes down one Lockheed Martin program, the F-22, Gates also boosts the F-35 program in order to avoid some of the political conflict (see Gates 2009; Hartung 2011: 14-15).
} 
hypothetical enemy in a future war for air supremacy...[while]... actual foes like the Taliban and al-Qaeda don't have an air force and are not interested in acquiring one (Preble 2009: 48)." However, the incentives of Lockheed Martin and Boeing were still directed towards competing for the contract, and once it became apparent that additions to the workforce would be available within their Congressional (or national, as with British Aerospace) district, political persons had the incentive to support whichever side offered a better advantage in terms of increased employment, regardless of the necessity for a JSF or which firm would be a more economically efficient producer.

The second point is the fact that the available windfall profits will lead entrepreneurs to seek out those gains via the political process which has long-term distortionary effects. ${ }^{26}$ In writing on the perils of institutional arrangements as a determinant of economic development, Coyne, Sobel and Dove (2010: 335) argue that "[w]here institutions encourage nonproductive activities, entrepreneurs will tend to exploit those opportunities. In doing so, they create subsequent non-productive opportunities. Each non-productive activity has a multiplier effect contributing to further decline." The process of discovery is no less important in the permanent war economy. With each new nonproductive activity, further avenues of nonproductive activity are provided.

As a way of illustrating this point, consider the example above, whereby the entrepreneurial discovery was made that linking programs to the politics of job creation was one way of gathering support for the sustainability of a defense program. While Lockheed Martin certainly did not originate this tactic in their appeals for the lucrative JSF contract, the firm was

\footnotetext{
${ }^{26}$ This second point is similar to the one made in section 3.1 above, yet it is important to stress that the section above spoke of the shift in entrepreneurship as one in which entrepreneurs attempt to generate demand for products that are inputs into national security. The following exposition will describe the shift in entrepreneurship as one in which the entrepreneurs are more concerned with capturing rents for their own firms and/or political aspirations rather than having concern for actual security.
} 
engaging in a tactic discovered previously within the military-industrial complex. This discovery has led to a variety of such endeavors, whereby efforts will be spent to construct new such technologies that can be sold as increasing the work force rather than as an input into national security. The same phenomenon can be seen in the lobbying attempts of the previously mentioned UAV industry. In her article on the drone lobby, Stone (2012) notes the comments by Association for Unmanned Vehicle Systems International (AUVSI) President Michael Toscano, where he argues the case for drone construction based on job creation, with AUVSI estimating that "drones would create 23,000 new jobs by 2025 ". The margins on which security is impacted need only be loosely tied to the program, as once it is accepted, a defense program finds Congressional support even as it enters the "perennial procurement and contracting cycle, going back many decades, of adding layer and layer of cost and complexity onto fewer and fewer platforms that take longer and longer to build..." (Gates 2009).

\section{Conclusion}

Our analysis has several implications. First, the costs of the war economy have been underestimated due to the lack of consideration for the full implications of a distorted private market economy and the negative effects on its vibrancy. The distortion is not a temporary effect, but one that has a lasting structural impact in both the military and non-military sectors. The permanency of the war economy ensures that resources will continuously be misallocated so long as the trend towards the alternative equilibrium remains. As the military-industrial complex lacks a mechanism for meaningful economic feedback and correction, once the economic activity has been set in motion, there is no true method of correction. 
This leads to the second implication, which is that the permanent war economy is selfextending. Throughout time, those misallocations will continuously build upon one another. The permanent war economy is self-extending because one profit opportunity creates several new, subsequent opportunities. A variety of ideas, each requiring a differing type or amount of resources, are involved in constructing new and better defense technologies. The discovery of a more technologically advanced radar system will create a further demand by the Departments of Defense and Homeland Security as the administrative decision makers seek marginal gains in the effectiveness of the radar without knowing whether those gains are economically worthwhile. If that demand is not reflective of an actual market demand for defense, then each additional unit created will be a further hindrance to economic efficiency.

A third implication is that the very institutions established to ensure national security and the resulting prosperity threaten to erode it. As mentioned in the introduction, the burden of excessive defense was recognized as early as Adam Smith. The efforts to protect the British Empire were proving to be the very undoing of that empire. The pressures of supporting the war economy were corrupting the private economy such that the costs of protection were destroying the very institutions that the defense was supposedly safeguarding. How far different is the British situation from the one faced by the United States today? The peace and prosperity that the military is supposed to defend is at peril, with that prosperity receding into the recesses of the war economy rather than being directed toward satisfying the wants of the people. ${ }^{27}$

As Mises ([1949] 2007: 659) argues, "[t]he government has no more ability than individuals to create something out of nothing. What the government spends more, the public spends less." The permanent war economy cannot remain on the outskirts of the non-military

\footnotetext{
${ }^{27}$ Mueller (2006) gives a compelling history of the events after 9/11, showing how the reactions of the security industries and political entities has pushed the American public even further from that peace and prosperity.
} 
economy in a neutral fashion. A mixed economy tends towards a fully controlled one until the point of crisis is reached (Ikeda 1997, 2005). The U.S. may be quickly approaching such a crisis, given its current levels of government spending and government debt. The defense spending will play its role in such an event. Yet even should the critical point not yet be reached, the diverted resources, both in terms of capital and the ingenuity and entrepreneurial spirit of the human mind, will be lost to non-military applications. The U.S., and the world as a whole, will be all the poorer for it. 


\section{References}

Bacevich, Andrew. (2010). Washington Rules: America's Path to Permanent War. New York: Metropolitan Books.

Belasco, Amy (2011). "The Cost of Iraq, Afghanistan, and Other Global War on Terror Operations Since 911," CRS Report for Congress. Retrieved from: http://www.fas.org/sgp/crs/natsec/RL33110.pdf

Bennett, Laurie (2012). "Drones in U.S. Air Space: The Next Lobby Frontier," First Street Research Group, May 1. Retrieved from: http://firststreetresearch.cqpress.com/2012/05/01/drones-in-u-s-air-space-the-next-lobbyfrontier/

Coyne, Christopher J., Russell S. Sobel, and John A. Dove (2010). "The non-productive entrepreneurial process," Review of Austrian Economics, 23: 333-346.

De Soto, Jesus Huerta (2010). Socialism, Economic Calculation, and Entrepreneurship: New Thinking in Political Economy, UK: Edward Elgar Publishing Limited.

Eisenhower, Dwight D. (1961). Farewell Address to the Nation, January 17, 1961. Retrieved from: http://www.h-net.org/ hst306/documents/indust.html

Friedman, Benjamin H. and Christopher Preble (2010). "Budgetary Savings from Military Restraint," Policy Analysis, no. 667: Cato Institute.

Friedman, Milton (1976). "Why Not a Voluntary Army," in Sol Tax, ed., The Draft: A Handbook of Fact and Alternatives, Chicago, IL: University of Chicago Press.

Gates, Robert (2009). "DoD News Briefing with Secretary Gates from the Pentagon,” U.S. Department of Defense Press Release, April 6, 2009. Retrieved from: http://www.defense.gov/transcripts/transcript.aspx?transcriptid=4396

--- (2010). "DoD News Briefing with Secretary Gates from the Pentagon," U.S. Department of Defense Press Release, August 9, 2010. Retrieved from:

http://www.defense.gov/transcripts/transcript.aspx?transcriptid=4669

Gates, Robert and Mike Mullen (2011). "DoD News Briefing with Secretary Gates and Adm. Mullen from the Pentagon," U.S. Department of Defense Press Release, May 18, 2011. Retrieved from: http://www.defense.gov/transcripts/transcript.aspx?transcriptid=4823

Hartung, William D. (2011). Prophets of War: Lockheed Martin and the Making of the MilitaryIndustrial Complex, NY: Nation Books. 
Hayek, F. A. (1945). "The Use of Knowledge in Society," The American Economic Review, 35(4): 519-530.

Henderson, David R. (2005). "The Role of Economists in Ending the Draft," Econ Journal Watch, 2(2): 362-376.

Higgs, Robert (1987). Crises and Leviathan: Critical Episodes in the Growth of American Government, NY: Oxford University Press.

--- (1993). "How Military Mobilization Hurts the Economy," in D.N. McCloskey, ed., Second Thoughts: Myths and Morals of U.S. Economic History, NY: Oxford University Press.

--- (2004a). Against Leviathan: Government Power and a Free Society, Oakland, CA: The Independent Institute.

--- (2004b). "Wartime Socialization of Investment: A Reassessment of U.S. Capital Formation in the 1940s," The Journal of Economic History, 64(2): 500-520.

--- (2005). Resurgence of the Warfare State: The Crisis since 9/11, Oakland, CA: The Independent Institute.

--- (2006). Depression, War, and Cold War: Studies in Political Economy, NY: Oxford University Press for the Independent Institute.

--- (2007). "Military-Economic Fascism: How Business Corrupts Government, and Vice Versa," The Independent Review, 12(2): 299-316.

--- (2012). Delusions of Power: New Explorations of the State, War, and the Economy, Oakland, CA: The Independent Institute.

Hoff, Trygve J. B. (1949). Economic Calculation in the Socialist Society, London, UK: William Hodge and Company.

Holcombe, Randall G. (1998). "Entrepreneurship and economic growth," The Quarterly Journal of Austrian Economics, 1(2), 45-62.

Ikeda, Sanford (1997). Dynamics of a Mixed Economy: Toward a theory of interventionism, London, UK: Routledge.

--- (2003). "How Compatible are Public Choice and Austrian Political Economy?" The Review of Austrian Economics, 16(1): 63-75.

--- (2005). “The Dynamics of Interventionism,” Advances in Austrian Economics, Vol. 8, pp. 2157.

International Institute of Strategic Studies (2010). The Military Balance 2010: The annual assessment of global military capabilities and defence economics, London. 
Kirzner, Israel M. (1985). Discovery and the Capitalist Process, Chicago, IL: University of Chicago Press.

Melman, Seymour, ed. (1971). The War Economy of the United States: Readings in Military History and Economy, NY: St. Martin's Press.

--- (1985). The Permanent War Economy: American Capitalism in Decline, New York, NY: Simon \& Schuster, Inc.

Mises, Ludwig Von. ([1920] 1990). Economic Calculation in the Socialist Commonwealth, Auburn, AL: Mises Institute.

--- ([1922] 1981). Socialism: An Economic and Sociological Analysis, Indianapolis, IN: Liberty Fund, Inc.

--- ([1929] 1996). Critique of Interventionism, Irvington-On-Hudson, NY: Foundation for Economic Education.

--- ([1949] 2007). Human Action: A Treatise on Economics, Indianapolis: IN: Liberty Fund, Inc.

Mueller, John (2006). Overblown: How Politicians and the Terrorism Industry Inflate National Security Threats, and Why We Believe Them, New York, NY: Free Press.

Mueller, John and Mark G. Stewart (2011). Terror, Security, and Money: Balancing the Risks, Benefits, and Costs of Homeland Security, Oxford, UK: Oxford University Press.

National Priorities Project (2011). “U.S. Security Spending Since 9/11" Retrieved from: http://nationalpriorities.org/publications/2011/us-security-spending-since-911/

--- (2010). "Discretionary Budget - FY 2011", Charts, Retrieved from: http://nationalpriorities.org/en/resources/federal-budget-101/charts/discretionaryspending/discretionary-budget-fy2011/

Neild, Barry (2012). “Not Just for Military Use, Drones Turn Civilian,” CNN, July 12. Retrieved from: http://www.cnn.com/2012/07/12/world/europe/civilian-dronesfarnborough/index.html

Oi, Walter Y. (1967). “The Economic Cost of the Draft,” The American Economic Review, 57(2): 39-62.

Pasztor, Andy and John Emshwiller (2012). "Drone Use Takes off on the Home Front," The Wall Street Journal, April 21. Retrieved from: http://online.wsj.com/article/SB10001424052702304331204577354331959335276.html 
Preble, Christopher A. (2009). The Power Problem: How American Military Dominance Makes Us Less Safe, Less Prosperous, and Less Free, NY: Cornell University Press.

Public Intelligence (2012). "DoD current and Future U.S. Drone Activities Map" Retrieved from: http://publicintelligence.net/dod-us-drone-activities-map/

Raymond, Jack (1964). Power at the Pentagon, NY: Harper and Row, Publishers, Inc.

Rockoff, Hugh (2012). America's Economic Way of War: War and the US Economy from the Spanish-American War to the Persian Gulf War, Cambridge, UK: Cambridge University Press.

Rothbard, Muray N. ([1962] 2001). Man, Economy, and State, Auburn, AL: Mises Institute.

Russet, Bruce M. (1971). "The Price of War," in Melman, Seymour, ed., The War Economy of the United States: Readings in Military History and Economy, NY: St. Martin's Press.

Schultz, Teri (2011). "More US Drones Patrolling above Border with Mexico," Global Post, December 6. Retrieved from:

http://www.globalpost.com/dispatch/news/regions/americas/united-states/111205/dronesus-border-mexico-drug-war-immigration

Schulz, G. W. (2012). "Homeland Security Business Growing for 2 Calif. Drone-Makers," The Bay Citizen, May 11. Retrieved from: http://www.baycitizen.org/homelandsecurity/story/homeland-security-business-growing-2/

Smith, Adam ([1776] 1976). An Inquiry into the Nature and Causes of the Wealth of Nations, Chicago, IL: University of Chicago Press.

Smith, R. Elberton ([1959] 1991). The Army and Economic Mobilization, D.C.: Center for Military History, United States Army.

Stone, Andrea (2012). "Drone Lobbying Ramps Up Among Industry Manufacturers, Developers," The Huffington Post, May 25. Retrieved from: http://www.huffingtonpost.com/2012/05/28/drone-lobbying-companies_n_1546263.html

Tax, Sol, ed. (1976). The Draft: A Handbook of Facts and Alternatives, Chicago, IL: University of Chicago Press.

Thomsen, Esteban. 1992. Prices and Knowledge. New York: Routledge.

Twight, Charlotte (1990). "Department of Defense Attempts to Close Military Bases: The Political Economy of Congressional Resistance," in Robert Higgs, ed., Arms, Politics, and the Economy: Historical and Contemporary Perspectives, Oakland, CA: The Independent Institute. 